\title{
PUBLIC PROCUREMENT IN ZIMBABWE: LAW, POLICY AND PRACTICE
}

\author{
James Tsabora
}

(2014) 1 APPLJ 1

\begin{abstract}
The increasing prominence of government in infrastructure construction and development and in the acquisition of public goods and services for public welfare provides a relevant opportunity to scrutinise public procurement laws and policies. In general, an efficient public procurement system enhances a government's public welfare role, particularly in Africa where governments are the major drivers for economic development in society. Further, determining the nature of a public procurement system, through analysis of the legislative and policy framework, clearly illustrates the political commitment in the fight against corruption and in a government's pursuit of important social and economic objectives. There is a particularly greater danger that the lack of a clear policy direction in this area, coupled with procurement laws that are difficult to enforce creates a breeding ground for corruption and establishes a system that lacks the necessary integrity. Further, there is the argument that inefficient and compromised public procurement frameworks are bound to create and regenerate corruption, misuse of public funds, poverty and consequently underdevelopment in general. In view of this, it is clear that effective public procurement regulation is a critical tool in public administration. This paper explores Zimbabwe's public procurement law and policy, arguing that relevant laws and policies should, as a matter of principle, create a transparent procurement system that instills business confidence. The paper therefore underscores the importance of public procurement as a necessary instrument in public administration and public finance management in Zimbabwe, and its role in advancing the government's social and economic objectives in general.
\end{abstract}

\section{http://applj.journals.ac.za}




\section{PUBLIC PROCUREMENT IN ZIMBABWE: LAW, POLICY AND PRACTICE}

James Tsabora

LLB LLM PhD

Lecturer, Midlands State University, Zimbabwe*

\section{Introduction}

Generally, public procurement is the purchasing by a government of the goods and services it requires to function and maximize public welfare. ${ }^{1}$ Public procurement is therefore an area where public administration and public finance management converge. For most developing countries, especially in Africa, public procurement is a critical yardstick in measuring government efficiency. This is because governments in these countries are the major drivers for economic growth and development, and perhaps the most important determinant in the acquisition and consumption of public services. Inefficient and compromised public procurement frameworks are bound to create and regenerate corruption, misuse of public funds, poverty and consequently underdevelopment in general. Certainly therefore, an effective system of public procurement is a critical tool in public administration and in government's efforts to maximize public welfare.

An examination of public procurement law and policy is necessary in the understanding of a public procurement system, and this paper seeks to undertake such task in three composite parts. The first part opens by exploring the policy framework and the impact of other government policies on the public procurement terrain. By making an exploratory diagnosis of the policy framework, this research searches for any discernible patterns and trends in government procurement policy, and examines the system's weaknesses and points of strength as well as exposure to corrupt tendencies and practises. In the second part, this paper scrutinises the legislative framework for public procurement, whose major law is the Procurement Act $^{2}$ giving particular preeminence to those provisions that critically impact on

\footnotetext{
*The author is grateful for the research assistance provided by Gloria Matambo, an intern at Office of Counsel, Parliament of Zimbabwe.

${ }^{1}$ See Arrowsmith and Trybus 2003:10.

${ }^{2}$ Chapter 22:14. For purposes of brevity, this paper will not dwell on the Procurement Regulations.
} 
corruption and the integrity of the procurement system. The third and final part ties the major arguments made throughout this paper and concludes by an appraisal of public procurement law and policy in Zimbabwe.

\subsection{The Policy Framework}

Since 1980, Zimbabwe has not drafted any White Paper on Public Procurement. This consequently means that to date, there is no official Procurement Policy framework that lays down the major pillars and technical features of public procurement. In the absence of such official "Procurement Policy", government's approach to procurement has to be gleaned from occasional official statements, other general economic policies and laws being implemented and finally other parafiscal and quasi-fiscal initiatives adopted at various periods in the last three decades. Even so, there is no clearer direction charted to indicate a comprehensive procurement policy trajectory. A White Paper on Public Procurement could have a gone a long way towards guiding and influencing most fiscal and monetary statements. Indeed, such a formal document could have easily defined the parameters of public sector procurement and the necessity for corresponding amendments to the law. It is no surprise therefore that the lack of a formal procurement policy means the government consistently fails to appreciate the need to promote efficiency in public purchasing practise or improve the ethical framework, particularly in view of wide-scale corruption and flouting of ethics in government departments. ${ }^{3}$

It is however important to note that the lack of a formal procurement policy has not deterred the government from following particular, albeit rough, approaches to public procurement. Most importantly, a starting point in identifying this rough approach is to regard Zimbabwe's public procurement system as a by-product of historical, political and economic developments in the past three decades. It can therefore be proposed that most developments in Zimbabwe's economic and corporate investment sector in particular, in the past thirty years have largely affected and shaped public procurement regulation. These developments have to be discussed in

\footnotetext{
${ }^{3}$ See Newsday 'Minister blasts State Procurement Board' May 5, 2014; Herald (Zimbabwe) 'Mega perks for tender boss ... raked in US $\$ 210$ 000-00 last year' May 27, 2014; ZBC 'State Procurement Board under scrutiny' 25 March 2014; Herald, 'Tender board admits to flouting procedures' 21 March 2014.
} 
order to provide a substantive context in which to understand Zimbabwe's public procurement terrain.

Since independence in 1980, the Zimbabwe government's intention has been to transform the economic sector such that more locally based and indigenous actors would be involved in the mainstream economy. Such a transformation was necessary because for the two decades between 1980 and about 2000, the ownership of Zimbabwe's vital economic sectors had remained in foreign hands, with the corporate sector heavily dominated by locally registered companies whose parent companies were domiciled or registered in Western countries. ${ }^{4}$ This large pool of companies included important corporations in civil construction, defence, mining, agriculture, retail, manufacturing, tourism and hospitality, transport and the financial sector. In essence, these companies were subsidiaries of foreign corporations in the West, but nevertheless passed the qualification of "indigenous" under Zimbabwe's corporate law. The government did not however ignore the need for economic relationships with other non European states. Thus, apart from respecting its relations with Europe and the USA, the government expended great efforts in strengthening economic relationships with important trading partners such as the South Africa and Asian countries, particularly China. These other relationship grew and developed significantly, thanks in small part to deteriorating political relations with the West (especially members of the EU) at the turn of the millennium. The thawing of relations with the EU saw a shift in economic and trade policy and directly resulted in the strengthening of political relations between Zimbabwe and Asian countries such as China, Indonesia and Malaysia. What eventually emerged between Zimbabwe and the Asian states (China, Indonesia and Malaysia, in particular) was the unwritten economic relationship now commonly referred to as "the Look East Policy" 5 in Zimbabwe

Throughout these political developments, the government increased its pace in "indigenization" ${ }^{\circ}$ of the economy on the domestic front. This was, and is still being pursued mainly through laws and policies that are intended at transforming

\footnotetext{
${ }^{4}$ See Chowa and Mukuvare 2013:7.

${ }^{5}$ For a discussion of this, see Maroodza 2011:1; Chigora and Chisi 2009:147.

${ }^{6}$ Under the Indigenization and Economic Empowerment Act, "indigenisation" refers to "a deliberate involvement of indigenous Zimbabweans in the economic activities of the country, to which hitherto they had no access, so as to ensure the equitable ownership of the nation's resources".
} 
ownership patterns in private capital and equity such that the corporate sector is eventually in the hands of "black" Zimbabweans. ${ }^{7}$ Clearly, this policy shift was further intended to completely transform the nature of "indigenous contractors" such that previously marginalized population groups could enter into mainstream economic activities, such as the procurement system. Indeed, aggressive indigenization policies seem to have seen the entry of more "black" owned companies and Zimbabwean contractors into the procurement system. Accordingly, the true and most recent description of major contractors in Zimbabwe's procurement system includes indigenous companies, Chinese contractors and few other East Asian firms, EU suppliers and South African companies.

The impacts of these political and economic developments on Zimbabwe's procurement system were immense. One of the most significant consequences of stronger trade and economic ties with China in recent years, for instance, is an increasing number of Chinese suppliers and contractors in the register of private contractors maintained by procurement authorities in terms of procurement regulations. In fact, the Zimbabwean government has awarded particularly civil construction contracts to an increasing number of companies from China in the past five years, with mixed results. ${ }^{8}$

\subsection{Specific Governmental Policy Initiatives}

It has been pointed earlier on that since 1980, there has not been any specific government's public procurement strategy. Since 2007 however, the government appeared to encourage and favour the acquisition of goods and services from the domestic market. This approach was unwritten, and at best not uniform, meaning that there continued to be governmental uncertainty on procurement policy. The emerging but hardly recognizable theme of domestic procurement was explained by government's indigenization economic approach, which was gradually developing in an aggressive manner. In 2007, the government adopted the Indigenization and Economic Empowerment policy and sought to implement it through the

\footnotetext{
7 See the Indigenization and Economic Empowerment Act. See critique of this legislation, its implications and impact in Matyszak 2011:10.

${ }^{8}$ See Daily News 'Chinese firms bungling tender awards' 30 June 2014; Herald 'Sino-Hydro awarded Hwange tender' 26 June 2014; Herald '(Chinese) Firm dupes SPB, ZPC on Hwange' 27 June 2014.
} 
Indigenization and Economic Empowerment Act. ${ }^{9}$ In essence, this policy and legal framework is aimed at "indigenizing" the economy by way of encouraging the transfer of majority percentage stakes and shares, thus ownership, from previously foreign owned companies into indigenous Zimbabwean hands. The policy framework is unclear and an examination of the Act can be useful to correctly describe the policy's true intentions.

The Act ushered in a new era in Zimbabwe's corporate industry. Its major premise was "to provide for support measures for further indigenization of the economy". ${ }^{10}$ In essence, this meant establishing a legal framework for the acquisition of majority shares by "indigenous" Zimbabweans in foreign owned or foreign controlled private companies. Its definition of "indigenous Zimbabwean"11 encompassed black Zimbabwean citizens only, and had the sweeping effect of excluding persons such as non-Zimbabwean nationals, white Zimbabweans in ownership of businesses in the country and even foreign persons who were permanent residents albeit owning businesses in Zimbabwe.

In relation to procurement, the Act obliged all "Government departments, statutory bodies and local authorities and all companies" to "procure at least fifty per centum of their goods and services required to be procured" under procurement legislation from those businesses in which indigenous Zimbabweans hold a controlling interest. ${ }^{12}$ In addition, the Act required that in any scenario where goods and services are procured in terms of procurement laws, albeit "from businesses in which a controlling interest is not held by indigenous Zimbabweans", any subcontracting that was required to be done by the supplier had to be necessarily done in favour of "businesses in which a controlling interest is held by indigenous Zimbabweans". ${ }^{13}$ The bias given to local suppliers and contractors in this section is very clear.

The theme of domestic procurement was also illustrated in the National Trade Policy (2009 - 2012). Apart from acknowledging the trade deficit caused by a high import

\footnotetext{
${ }^{9}$ Chapter 14:33.

${ }^{10}$ See short title of the Act.

${ }^{11}$ In terms of section 2(1) of the Act states that an indigenous person is "any person who, before 18th April, 1980 was disadvantaged by unfair discrimination on the grounds of his or her race, and any descendant of such person, and includes any company, association, syndicate or partnership of which indigenous Zimbabweans form the majority of members or hold the controlling interest".

${ }^{12}$ Section 3 (1) (f) of the Indigenization and Economic Empowerment Act.

${ }^{13}$ Section 3(1) (g).
} 
bill that far exceeded export earnings, the Trade Policy urged consumers of goods and services to promote consumption of locally manufactured goods and services, and hoped for industrial revival that would influence a paradigm shift to this effect. ${ }^{14}$ In specific terms, the Policy stated that the Government would "endeavour to give priority to local producers of goods and services for its procurement requirements," and strongly encouraged industry and commerce "to source their raw materials and inputs locally where these are readily available". ${ }^{15}$ This aspiration was no mere wish as the government pressed on with various legal restrictions against foreign procurement. In 2010, for instance, the government stepped up its implementation of the indigenization law when it passed the regulations to the Act that spelt the modalities of how the Act's objectives would be achieved.

Some of the most drastic provisions of the Regulations provide that every business with an asset value of or in excess of a prescribed amount has to, "cede a controlling interest of not less than $51 \%$ of the shares or interests therein to indigenous Zimbabweans" within five years, unless a lesser share, or longer period within which to achieve the indigenization is justified. ${ }^{16}$ Implementation of this provision would definitely transform the face of Zimbabwe's corporate investment and industry, with indigenous black Zimbabweans ending up in control of previously foreign owned corporate entities.

Recently, the government has acknowledged that the public procurement system is in great need of repair. For instance, whilst delivering the 2014 National Budget Statement, the Minister of Finance restated some of the objectives of Zimbabwe's procurement framework, and these included accountability in public resource management, achieving value for money and finally, transparency and efficiency in procurement procedures. ${ }^{17}$ It seems clear, from the Budget Statement's perspective, that the current approach to procurement has long been ineffective, with the Statement proposing the complete 'revamp' of the 'public procurement arrangements and processes to achieve efficient, transparent, accountable and professionally

\footnotetext{
${ }^{14}$ National Trade Policy 2009 - 2012, para 6.3.4.

${ }_{16}^{15}$ National Trade Policy, para 6.3.4

${ }^{16}$ Section 3(a) and (b) of the Indigenization and Economic Empowerment (General) Regulations, 2010, which were gazetted on $29^{\text {th }}$ January 2010, effective $01^{\text {st }}$ March 2010.

172014 National Budget Statement paras $438-443$.
} 
managed systems that enjoy high level of business confidence and ensure consistent attainment of best value for money. ${ }^{18}$

Amidst the furore generated by various laws and policies that directly or incidentally impacted on public procurement in Zimbabwe, there is no doubting that at least, from a procurement policy perspective, the intention of the government was to decrease the number of foreign firms in Zimbabwe's mainstream economic activities. Such a decrease would, the government hoped, lead to an increase in Zimbabwean firms controlling the economy, and thus an increase in Zimbabwean owned companies that would be contractors and suppliers under the public procurement system.

The downside of the restrictions against foreign procurement is however that they would definitely be difficult to enforce in view of the critical capacity challenges faced by local manufacturers and industry at large. Zimbabwean industry is caught in an unending economic and financial spiral and has been operating well below full potential in the past decade. That the same industry face challenges in delivering and performing is clear. The subcontracting provisions do not ameliorate this situation at all. At best, the subcontracting provisions are bound to lead to the creation of local predatory shelf companies waiting to pounce as mere middlemen, but lacking capacity and competence. Such shelf companies cannot hoist the country's public procurement system on their own. Thus, in view of this, one might argue that the logic and direction of the provisions of indigenization law that directly impact public procurement is difficult to follow, justify or defend.

A further and even more dangerous consequence of such policies derives from the identity of individuals in control of the emergent indigenous "corporate sector". Most of the individuals who have taken advantage of the economic policies are influential government officials and other powerful high ranking political officers with access to funds and capital. ${ }^{19}$ By using its powerful influence and relevant governmental connections, this elite group of corporate actors finds it easy to manipulate the procurement system and obtain preferences from institutions established under

\footnotetext{
${ }_{10}^{18}$ National Budget Statement 2014, para 443.

${ }^{19}$ See for instance The Standard 'Indigenization: Public policy for private gain" September 3, 2010.
} 
procurement legislation. Such a scenario erodes the integrity of the public procurement system and damages system transparency.

Ordinarily, government policy is reflected in the law, and is thus enforced through its application. This is aptly exemplified by the indigenization policy that has been implemented mainly through indigenization legislation. In Zimbabwe, public procurement regulation is governed by the Constitution and the Procurement Act, ${ }^{20}$ and its Regulations. The content of this law clearly needs examination. For instance, there is need to highlight the extent to which the Act's provisions correspond with general procurement policy objectives? Can the existing legal framework guarantee transparency, cost effectiveness, best value and integrity of the system, which are important objectives of public procurement regulation? Most importantly, in what way, and to what degree does the law ensure accountability and fairness whilst guarding against political manipulation, corruption and inefficiency? The following part explores and scrutinises these major questions and themes with a view at providing a comprehensive analysis of Zimbabwe's procurement legal framework.

\section{The Legal Framework for Public Procurement}

\subsection{The Constitution}

The Zimbabwean Constitution ${ }^{21}$ goes some distance towards determining public procurement objectives that the public procurement system should aspire to achieve. Section 9 of the Constitution is a mandatory call for the government to 'adopt and implement policies and legislation to develop efficiency, competence, accountability, transparency, personal integrity and financial probity'. In the least, this section fully captures the most important aspirations of procurement policies. It could be argued that on the basis of this section alone, government procurement policies that stifle a competitive and robust regime, that fails to promote financial probity, fairness or accountability, falls foul of the Constitution. Further, legislation and procurement policy approaches that restrict the entry of many players, and favours particular

\footnotetext{
${ }^{20}$ Chapter 22:14

${ }^{21}$ The current Zimbabwe Constitution was adopted in 2013 as Constitutional Amendment No. 20, following a national referendum. It replaced the 1980 Lancaster House Constitution adopted by the country at its political independence, and which was published as SI 1979/1600 in the United Kingdom.
} 
suppliers of goods and services on the basis of their nationality, origin or race, or that encourages corrupt practices can be challenged under section 9.

Apart from the above provisions, the Equality clause in section 56 of the Zimbabwean Constitution further guarantees equal opportunity and fairness. The section prohibits unfair discrimination on grounds of nationality, race, colour, place of birth, ethnic and social origin, economic or social status among other categories. It is important to note that the fact that this section states that 'all persons' means that the extent of protection guaranteed in the equality clause is not restricted to Zimbabwean citizens only. It applies with equal measure to foreign citizens, or germane to this paper, foreign suppliers and contractors doing business in, or with Zimbabwe.

Accordingly, under section 56, legislation or policy practices that unfairly discriminate against a certain category of foreign or domestic suppliers and contractors in favour of others is bound to be unconstitutional. Indeed, section 56 clearly specifies kinds of discrimination that are prohibited. In section 56 (4) (a), it is regarded as discrimination when persons are "subjected, directly or indirectly to a condition, restriction or disability to which other people are not subjected". In terms of section 56 (4) (b), the practice of according other people directly or indirectly a privilege or advantage to which other people are not accorded is regarded as discriminatory treatment.

The above notwithstanding, it is important to note that section 56 is not blind to the need for forms of unequal treatment that are prima facie discriminatory, but substantively aimed at advancing particular social goals. Indeed, the provisions grant the government leeway to implement other social goals through procurement policy that could prima facie appear to be favouring particular groups over others. ${ }^{22}$ For instance, the government could adopt, or defend procurement policy that favours social groups that were previously economically undermined with a view to enhancing economic opportunity and attaining particular economic objectives.

The Indigenization and Economic Empowerment policy is a clear example of policies that could be defended in terms of section 56 . In particular, it could be argued that

${ }^{22}$ Bolton 2003:194. 
this policy, among other goals, is aimed at recognizing, supporting and empowering newly emerging suppliers and contractors who were hitherto not involved in the procurement system. Such a policy is not substantively inconsistent with section 56 . In fact, section 56 (5) recognises that the discrimination can be permitted if it is shown that it is 'fair, reasonable and justified in a democratic society' based on openness, justice, human dignity, justice, freedom and equality. ${ }^{23}$ Under section 56 (6), the State is permitted to adopt such policies for the purposes of achieving equality and advancing or protecting the interests of previously undermined social groups.

Further, albeit on a different note, section 56 can ensure transparency and integrity in government procurement since it can be used to challenge procurement proceedings and decisions of procurement entities. Losing bidders and suppliers can rely on this section to commence 'protest actions' in the form of reviews, appeals, or submissions to relevant authorities challenging the award of tenders on the basis of unfairness or some other recognized grounds. By so permitting, section 56 , and thus the Constitution, safeguards against bribery, unjustified preferential treatment, unethical behaviour and favouritism in the selection of proposals, suppliers and contractors.

The Constitution, it should however be admitted, provides a very skeletal framework that is important albeit as a starting point. Critical provisions that establish and pronounce a workable legal framework are found in legislation that is passed to give effect to the Constitution's provisions. The Procurement Act is one such law.

\subsection{The Procurement Act}

The Procurement Act predates the Constitution, having been passed in 1999. ${ }^{24}$ However, its philosophy can easily relate to the economic principles and values mentioned in the Constitution's provisions discussed above. Accordingly, a study of the main features of this Act certainly sheds light on public procurement regulation in Zimbabwe.

\footnotetext{
${ }^{23}$ Every constitutionally entrenched right and freedom is limited in terms of section 86 of the Constitution.

${ }^{24}$ It was passed as Act 2 of 1999, albeit its date of commencement is $01^{\text {st }}$ August 2001.
} 


\subsubsection{Application and Administration of the Act}

The Act applies to all procurement entities, defined in section 1 to mean any of three bodies, namely (a) the State Procurement Board, (b) any (i) Ministry, department or other division of the Government; or (ii) statutory body that engages in procurement; or (c) any local authority or person declared under subsection 2 to be a procuring entity. It is clear from this definition that the Act applies to, and affects procurement by arms or organs or institutions of government, or those subsidiary bodies that carry out procurement on behalf of these governmental institutions. Essentially, the Procurement Act regulates procurement of both central and local government. ${ }^{25}$

In relation to administration, the President determines the Ministry responsible for the administration of the Act. Thus, the President may from time to time assign a Minister or the Vice President the administration of the Act. The Ministry of Finance (Treasury) is only responsible for financing governmental contracts and contract supervision and monitoring. Currently, in practice, the State Procurement Board reports to the President, not the Ministry of Finance. ${ }^{26}$ The Office of the President and Cabinet (OPC) appears happy with retaining the responsibility of administering the Act. The fact that the Office of the President and Cabinet has been given a number of responsibilities in the Act further suggests that the Legislature intended the Office of the President and Cabinet to be directly responsible for the administration of the Act.

The problem with this scenario is that institutions established by the Act, are bound to be directly affected by mainstream politics of the day that originates within the

\footnotetext{
${ }^{25}$ The Urban Councils Act seems to provide for a separate procurement framework for local councils. For instance, section 210 of the Act provides that "Every municipal council shall appoint a municipal procurement board consisting of not less than five and not more than seven members, which shall be responsible for arranging tenders in terms of section two hundred and eleven and for making recommendations to the council in regard to the acceptance of tenders and the procurement of goods, materials and services." It appears that the Legislature had wanted to centralize government procurement by the repeal of section 210 by the Procurement Act when it broadened the application of the Act to cover 'local councils' which had not been the case previously. The fact that such repeal did not materialize seems to mean that local councils are able to continue conducting procurement proceedings on their own as they were doing previously.

${ }^{26}$ Section 21 provides that the Board reports to the Minister. If the Office of the President has assigned itself the responsibility of administering the Act, the Board reports directly to the President. Interviews made by the author with officials in the Ministry of Finance confirmed that the Board reports to the President.
} 
Office of the President and Cabinet. Statutory bodies set up under the Act are bound to be perceived, or perceive themselves, as being part of the Executive. This creates the impression that these institutions are not necessarily corporate, but political and are free to overlook or ignore critical corporate governance measures in order to pursue or satisfy political objectives. An analysis of the State Procurement Board, a critical institution under the Act, becomes necessary.

\subsubsection{The State Procurement Board}

Part II of the Procurement Act is dedicated to the establishment, functions, composition of the State Procurement Board ("the SPB"). The fact that the Act dedicates twenty sections to the SPB makes Part II the longest and perhaps most important part of the Act. Logically, this could be interpreted to mean that the whole Act revolves around the SPB; at least in the eyes of the lawmaker, the SPB is thus a vital institution in government procurement.

The Act opens by stating that the SPB shall be a body corporate, and thus capable of suing and being sued in its own name. ${ }^{27}$ This means that in discharging its statutory mandate, it shall act as any other corporate institution, albeit with the duty of conducting governmental procurement. This is welcome as it increases accountability and encourages corporate governance within the institution.

\subsubsection{Functions and Composition of the SPB}

The functions of the SPB are clearly spelt out. The Act provides these as (a) conducting procurement on behalf of procuring entities, (b) supervision of procurement proceedings conducted by procuring entities, to ensure compliance with the Act, (c) investigations in terms of section 46, and (d) performance of any other act conferred or imposed on the SPB by the Act or any other law. ${ }^{28}$ The functions of the Board echoes the point mentioned above; that the SPB is an entity essentially set up to conduct government procurement.

\footnotetext{
${ }^{27}$ Section 4.

${ }^{28}$ Section 5 .
} 
There is little doubt that the functions of the SPB are essentially of a commercial nature. This means that, as a corollary, its members ought to have a commercial background in order to fully discharge their mandate. The Act caters for this in an interesting manner; at least "three members shall be appointed from a list submitted by recognized chambers of business, industry, commerce and other professional bodies." 29 This might not be enough; the Act could have specified the exact business or commercial qualifications and experience needed for a member to be appointed to this Board. The fact that recognized chambers of business or commerce are required to nominate persons does not mean such persons will be able to fully and competently discharge the duties and responsibilities stated in the Act. These persons may fail to handle procedures due partly to the huge amounts of money involved and extensive contracts such as those known as public sector investment projects in Zimbabwe.

Without doubt, executive political appointments as is the case with the SPB ignores the importance of professional technocrats and creates a real possibility that SPB members would be more politically aligned and thus amenable to political manipulation. Once this becomes the case, its decision makers could fail to tie bureaucratic rules and budgets to specific goals, thus compromising the integrity of the institution.

The members of the SPB are appointed by the President, who also determines conditions of service and has discretion to renew the contracts of, or re-appoint, members. ${ }^{30}$ Apart from the ordinary members, the President directly appoints the chairperson and the vice chairperson. He further has power to suspend ${ }^{31}$ or require that members vacate office on certain grounds. ${ }^{32}$ It is clear that this section means that the tenure of office of members is at the discretion of the President and members are answerable to the Office of the President for their conduct, performance and in discharging their duties. Again, it is not difficult to see the possibility of political considerations getting in the way of professionalism in appointment, tenure of office and discharge of the statutory mandate.

\footnotetext{
${ }^{29}$ Section 6(2).

30 Section 6 and section 13.

31 Section 11.

32 Section 10 (3).
} 
Executive control over the ordinary operations of the SPB is manifest throughout the Act. For instance, the Act empowers the President to "give general written directions of policy to the State Procurement Board" and the Board has a mandatory obligation "to take all necessary steps to comply with them." ${ }^{33}$ In terms of section 21, the Board reports to the Minister, and submits special reports, annual reports and monthly reports to him. Under section 19, the President is responsible for fixing remuneration of members of the SPB, and this includes salaries and allowances. The danger is that public procurement is a sphere of government activity and therefore one of the key areas in which bureaucratic corruption manifests. ${ }^{34}$ By failing to prioritize corporate accountability, the Act creates a dangerous scenario where political accountability is more important than corporate responsibility, thereby preparing a seedbed for political manipulation.

It should be commended that the Act goes some way, at least on paper, towards promoting integrity. Section 9 of the Procurement Act insists on the integrity of the "chairman" of the Board through prohibiting him from engaging in any other business occupation and placing the requirement for disclosure of assets and their value, as well as the business of spouses of SPB members. To some extent, these standard measures seek to prevent instances of conflicts of interest that would endanger the integrity of SPB proceedings. It is a criminal offence to violate these provisions and members face expulsion. It can however be argued that the increasing sophistication of organised crime and technological advancement in the modern age means persons can easily hide their assets and hedge them from the public eye. In practise therefore, these provisions are difficult to enforce.

\section{Procedures and Proceedings}

Procurement proceedings should as a matter of necessity ensure the achievement of the constitutional imperatives of establishing a system that enhancing "efficiency, competence, accountability, transparency, personal integrity and financial probity”. 35 Part IV of the Procurement Act regulates the procedures and proceedings of public

\footnotetext{
${ }^{33}$ Section 20 (1).

${ }^{34}$ See The Chronicle "Overhaul operations of the State Procurement Board" 22 March 2014.

${ }^{35}$ Section 9 of the Constitution.
} 
procurement. There is a distinction made in terms of form and nature of procurement proceedings for goods and construction on one hand, and for services on the other. In essence, however, the form and method is almost similar for procurement of both goods and services and construction, and for services. ${ }^{36}$ Further, for both forms of procurement proceedings, there is a mandatory obligation on the procurement entity to "conduct its tendering proceedings in accordance with procurement regulations" and to ensure that the procedures adopted ensure fair and impartial treatment of suppliers. ${ }^{37}$

The Act is clear on a number of issues relating to procurement for both goods and construction work and for services. For instance, the Act clearly provides for the nature and manner of publication of invitation to tenders, standard form requirements for bids and proposals, criteria for evaluation of bids and proposals, access to relevant information and official documents, description of goods, services and work being put to tender, provisions for security deposit and other matters. ${ }^{38}$ The actual tendering and bidding proceedings and final evaluation are the subject of Procurement Regulations, ${ }^{39}$ which are made by the Minister, in consultation with the Minister responsible for finance and the SPB. On paper, in the least, the procurement regulations provide clear rules of conduct for procurement personnel in the government and in the private sector. These rules, if complied with, and actively enforced, can guard against bribery, favouritism, unethical behaviour, preferential treatment and, can ensure fair, impartial evaluation of contract proposals.

It should be mentioned that, for the private sector, perceptions regarding system transparency in government procurement are a critical element for purposes of business confidence. Private contractors and prospective suppliers have to be convinced that the existing procedures ensure fairness and impartiality. This is usually through publication of all statutes and regulations, clarifications on government requirements, and the existence of protest (appeal) ${ }^{40}$ procedures. $^{41}$ The

\footnotetext{
${ }^{36}$ See section 30 .

${ }^{37}$ Section 31 (2) [goods and construction work] and section 32 (2) [services].

${ }^{38}$ See section 31 and section 32 .

${ }^{39}$ Section 33(1).

${ }^{40}$ Section 43 provides for appeal procedures against a decision of the SPB in procurement proceedings, and in cases of debarment (section 41).

${ }^{41}$ See Schooner 2002:108.
} 
Procurement Act adequately covers these aspects and in clear terms, with the Regulations clearly providing a comprehensive framework for the technical aspects.

\section{Debarment and Blacklisting}

Procurement legislation usually makes provision for the debarment and blacklisting of contractors and suppliers from government contracts, with the effect that these contractors are denied access to public contracts. In most jurisdictions, this mechanism or debarment, also known as disqualification, is a punitive measure. The exclusion of contractors is often for a stated period of time, and once a particular contractor is sanctioned thus, that contractor is banned from contracting with the government during that period of time. Debarment measures are triggered mainly in two situations, namely as a response to violations and breaches of anti-corruption laws and also as punishment for past violations of procurement procedures and processes. Breaches that are usually considered, and thus common, include violations of anti-corruption laws through acts such as bribery, theft, embezzlement, fraud, forgery, falsification of financial records, tax evasion, and money laundering among others.

The Procurement Act makes provision for debarment measures under section 41. In terms of this section, the State Procurement Board is competent to declare a supplier ineligible to be awarded a State contract for two reasons. Firstly, if that supplier has been convicted for essentially fraudulent activities listed in section 48 of the Act, or for violating provisions of the Prevention of Corruption Act, it may be debarred. ${ }^{42}$ Section 48 lists procurement offences as including deliberate misrepresentation of material facts in tenders, bids or proposals, and collusion between suppliers relating to quoting of prices in tenders, bids or proposals. ${ }^{43}$ However, the violation of the stated provisions must be in respect of procurement proceedings in which the State or a statutory body was the procuring entity. This means that a supplier may not be debarred if it committed the breaches specified in section 41 whilst contracted to other private parties that are not governmental entities.

\footnotetext{
${ }^{42}$ Section 41(1).

${ }^{43}$ Section 48 (a) and (b).
} 
The second scenario that triggers debarment measures is when a procurement contract between the State and a contractor or supplier is cancelled or terminated on account of fraud on the part of the supplier. ${ }^{44}$ It should be noted that debarment applies only with respect to government contracts. Debarred contractors and suppliers are not debarred from entreating and contracting with non-governmental parties or institutions.

The existence of debarment provisions in the Procurement Act shows a measure of government commitment to maintain system integrity and guard against corruption. It further demonstrates government commitment at punishing unethical behaviour that can sully its procurement framework. This is because in view of the huge sums of money involved, private suppliers and contractors have a propensity to commit misconduct or flout applicable rules in order to obtain government contracts. Private contractors obtain a huge chunk of contracts from the government in Zimbabwe, and to these contractors, debarment is akin to "death penalty". Denying private contractors access to governmental contracts goes some way in deterring misconduct whilst simultaneously maintaining public trust in the procurement system.

Despite making provision for debarment measures, it can be argued that the provisions are too cautious and restricted. For that reason, they may not sufficiently deter misconduct by current or prospective suppliers and contractors. For instance, the SPB needs to consider the past professional conduct of private contractors, not only in their dealings with the government, but also in their private dealings as well. The SPB should open both eyes and determine whether or not it would be prudent to deal with infamous private parties and risk taxpayers funds by awarding such parties huge governmental contracts. It is strongly contended that there is need to consider appropriate restrictions against private contractors notorious for mal-performance, or for fraudulent activities in dealings with other private contractors. Contractors with a record for lack of business integrity, illicit acts of bribery and other dishonest acts should not be considered for a specific period. Such mechanisms could guard

${ }^{44}$ Section $41(2)$. 
against wasting the taxpayer's money in government's hand and would, no doubt, go a long way in enabling the government to achieve best value for its money.

Apart from this, the danger of politically manipulated decision making cannot be ruled out. Excessive executive control of the SPB, outlined above, means it might not be easy to blacklist or debar politically connected private contractors. Consequently, the Executive is likely to have the final say on who to contract with at any given time and such decisions will have to be implemented by the SPB notwithstanding the past professional (mis)conduct of private suppliers. For Zimbabwe, corporations are known for queuing in order to contribute to political party funding during critical political elections and other activities of political parties. The quid pro quo relationship that develops is bound to determine the incidence of contractual relationships between the political parties in power and such corporations. Such corporations might have a notorious record of mal-performance, tax evasion or other misconduct, but their political connections ensure that they are never subjected to debarment.

\section{Conclusion}

This paper interrogated the major features of Zimbabwe's public procurement law and policy. It has been observed that the policy framework is less than clear and an attempt at examining its major pillars is almost a thankless exercise. In discussing general procurement 'policy', this paper scrutinized official documents such as budgets, other economic policies and legislation such as the Indigenization and Economic Empowerment Act. From such scrutiny, it was easy to conclude that there is an appreciation of the general objectives of an efficient procurement system in official circles. It is also not difficult to understand that the government's 'policy' thrust has been to promote domestic procurement, or to prefer doing business with domestic suppliers and contractors, at least on paper. On the ground, such a position is flawed in view of the crippling economic challenges that affect Zimbabwe's industry and manufacturing sector, and thus their capacity to deliver and perform. 
An analysis of public procurement law discloses excessive executive control of the State Procurement Board. The political orientation that underpins the establishment of this Board and its functionality means that it is highly susceptible to political manipulation and consequent corruption. That such manipulation engenders corruption is not difficult to accept in a country that has recorded rampant corruption in state run businesses and government entities. As mentioned above this corruption tide has already knocked on the procurement system itself, with damaging consequences to business confidence in the system. The highly executive and thus political nature of the SPB means it is exposed to governmental corruption, which is unfortunate since the procurement system is especially designed to negate conditions for corruption. Further, the emergence of new Zimbabwean owned corporate entities willing to do business with the government has increased political pressure for the SPB to bear as this new class is mainly made up of politicians and government officials. In view of this and other challenges, one is bound to conclude that public procurement regulation in Zimbabwe is fundamentally flawed and cannot be used to fight rampant corruption. The system, it has to be concluded, needs a complete overhaul. 


\section{BIBLIOGRAPHY}

\section{Books}

Arrowsmith, S and Trybus, M 2003. Public procurement: The continuing revolution Kluwer Law International.

\section{Articles}

Bolton, P. 2003. Government procurement as a policy tool in South Africa. Journal of Public Procurement 6:3: 193 - 217.

Chigora, P and Chisi, T.H. 2009.The eight years of interaction: Lessons from Zimbabwe's Look East Policy and the future of African countries and Asia-Pacific region. Journal of Sustainable Development in Africa 10:4: 147-161.

Chowa, T and Mukuvare, M. 2013. An analysis of Zimbabwe's Indigenisation and Economic Empowerment Programme (IEEP) as an economic development approach. Journal of Economics 1:2: 1-18.

Maroodza, R.G. 2011. The socio-economic dimensions of Zimbabwe's Look East Policy. Berkeley Journal of Social Sciences 1:4: 1-11

Matyszak, D. 2011. Everything you wanted to know (and then some) about Zimbabwe's Indigenisation and Economic Empowerment Legislation but quite rightly were too afraid to ask. Research and Advocacy Unit 1- 42.

Schooner, S.L. 2002. Desiderata: Objectives for a System of Government Contract Law. Public Procurement Law Review 11: 103 - 119.

\section{Newspaper articles}

The Chronicle . 'Overhaul operations of the State Procurement Board. 22 March 2014, available at http://www.chronicle.co.zw/editorial-comment-overhauloperations-of-state-procurement-board/ accessed on 20 July 2014.

Newsday 'Minister blasts State Procurement Board' May 5, 2014 available at https://www.newsday.co.zw/2014/05/05/minister-blasts-state-procurement-board/ accessed on 19 July 2014 ;

The Herald. 'Mega perks for tender boss ... raked in US\$210 000-00 last year' May 27, 2014; available at http://www.herald.co.zw/mega-perks-for-tender-boss-raked-inus210-000-in-allowances-last-year-zimra-wants-its-pound-of-flesh/ accessed on 05 August 2014. 
ZBC. 'State Procurement Board under scrutiny' 25 March 2014; available at http://www.zbc.co.zw/index.php?option=com content\&view=article\&id=42651: stateprocurement-board-under-scrutiny\&catid=41:top-stories\&ltemid=86 accessed on 27 June 2014.

The Herald. 'Tender board admits to flouting procedures' 21 March 2014; available at http://www.herald.co.zw/tender-board-admits-to-flouting-regulations/ accessed on 10 August 2014

Daily News. 'Chinese firms bungling tender awards' 30 June 2014; available at http://www.dailynews.co.zw/articles/2014/06/30/chinese-firms-bungling-tenderawards accessed on 17 July 2014.

The Herald. 'Sino-Hydro awarded Hwange tender' 26 June 2014; available at http://www.herald.co.zw/sino-hydro-awarded-hwange-tender/ accessed on 27 June 2014.

The Herald. 'Firm dupes SPB, ZPC on Hwange' 27 June 2014; available at http://www.herald.co.zw/firm-dupes-spb-zpc-on-hwange/ accessed on 27 June 2014.

The Standard. 'Indigenization: Public policy for private gain" September 3, 2010; available at http://www.theindependent.co.zw/2010/09/03/comment-indigenisationpublic-policy-for-private-gain/ accessed on 28 June 2014.

\section{Official Government Documents}

National Budget Statement 2014, Ministry of Finance, Zimbabwe.

National Trade Policy 2009 - 2012, Ministry of Industry and Commerce, Zimbabwe.

\section{Legislation}

Constitutional Amendment Act No. 20, 2013.

Indigenisation and Economic Empowerment (General) Regulations, 2010.

Indigenization and Economic Empowerment Act Chapter 14:33

Procurement Act Chapter 22:14.

Procurement Regulations, Statutory Instrument 17 of 2002.

Urban Councils Act Chapter 29:15. 